\title{
Morphometrics and carcass characteristics of males of six dual purpose chicken breeds under intensive management
}

* Oyewale, O. A., Bamidele, O., Oyedele, J. G. and Sonaiya, E. B.

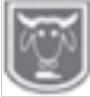

African Chicken Genetic Gains - Nigeria, Department of Animal Sciences, Obafemi Awolowo University, Ile-Ife, Osun State, Nigeria

Abstract

Corresponding author:*fikayooyewale@gmail.com

\begin{abstract}
The performance of six dual-purpose, smallholder-focused chicken breeds (Fulani, FUNAAB Alpha, Kuroiler, Noiler, Sasso and Shikabrown ${ }^{\circledR}$ ) was evaluated under intensive management at two locations in Nigeria. Data on live performance, morphology, physiology and carcass characteristics were collected. Adaptability characteristics were higher in Fulani, FUNAAB Alpha and ShikaBrown breeds. Kuroiler, Sasso and FUNAAB Alpha had higher $(p<0.05)$ morphometric indices. Carcass characteristics were higher $(p<0.05)$ for Kuroiler, FUNAAB Alpha, Noiler and Sasso breeds. Noiler and Sasso had the highest dressing percentage (69.2\%) and muscle to bone ratio (2.8), respectively. The physiological characteristics of the breeds fell within the normal range for chickens. The six breeds were well adapted to the hot humid environment of Nigeria.
\end{abstract}

Keywords: agro-ecology, morphology, physiology, smallholder poultry

\section{Des Caractéristiques morphométriques et carcasses des mâles de six races de poulet à double usage sous gestion intensive}

\section{Résumé}

$\bar{L}$ a performance de six races de poulets à double usage et axées sur les petits exploitants (Fulani, FUNAAB Alpha, Kuroiler, Noiler, Sasso et Shikabrown $\left.{ }^{\circledR}\right)$ a été évaluée sous gestion intensive à deux endroits au Nigéria. Des données sur les performances en direct, la morphologie, la physiologie et les caractéristiques de la carcasse ont été recueillies. Les caractéristiques d'adaptabilité étaient plus élevées chez les races peuls, FUNAAB Alpha et ShikaBrown. Kuroiler, Sasso et FUNAAB Alpha avaient des indices morphométriques plus élevés $(p<0,05)$. Les caractéristiques de la carcasse étaient plus élevées $(p<0,05)$ pour les races Kuroiler, FUNAAB Alpha, Noiler et Sasso. Noiler et Sasso avaient le pourcentage d'habillage le plus élevé (69,2\%) et le rapport musclelos (2,8), respectivement. Les caractéristiques physiologiques des races se sont tombées dans la fourchette normale pour les poulets. Les six races étaient bien adaptées à l'environnement chaud et humide du Nigeria.

Mots-clés: agro-écologie, morphologie, physiologie, volaille à petits exploitants

\section{Introduction}

Smallholder chicken (SHC) production in Nigeria, as well as many other developing countries, is defined by raising of mostly indigenous breeds which are well adapted to the local climate. SHC accounts for $83 \%$ of the total adult chicken population (under traditional and commercial production systems) in Nigeria, and plays important roles in household income and nutrition of SHC farmers (Sonaiya and Swan, 2004). Chicken breeds usually raised under SHC production system are generally light weight birds, attaining body weight of 800 to $1,200 \mathrm{~g}$ at 224 days (Sonaiya et al., 1999). The dominant purpose of rural SHC production as expressed by 1,200 farmers surveyed in five states of Nigeria in 2015- 


\section{Morphometrics and carcass characteristics of males of six dual purpose chicken breeds}

2016 was family meat consumption, followed by sale of live adult chicken (ACGG Nigeria Baseline data 2016, http://data.ilri.org/portal/dataset). These two production objectives depend on the live performance, morphology and carcass characteristics of chickens. In addition, physiological characteristics which show the response of birds to environmental factors indicate how adapted the birds are to the local environment. The general objective of this study was to investigate the performance of six dual purpose chicken breeds when raised under intensive production management, generating data that can be useful to breeders. The specific objectives were: i) to compare the live performance of cocks from the breeds; ii.) to compare their morphometric measurements; iii) to measure their physiology and hematology; iv) to compare their carcass yields; and v) to determine the proximate contents of their muscles.

\section{Materials and methods Studylocations}

The birds were reared intensively on deep litter at two stations in Nigeria: one located in Ibadan, Oyo State (within the Southern Guinea Savanna Zone - SGS) and the other in Abeokuta, Ogun State (in the Dry Lowland Rain Forest Zone - DLRF). The coordinates of the two stations were: latitude $7^{\circ} \mathrm{N} 20^{\prime} 25^{\prime \prime}$, longitude $3^{\circ} \mathrm{E} 58^{\prime} 14^{\prime \prime}$ and altitude $4.5 \mathrm{~m}$ for SGS, and latitude $7^{\circ} \mathrm{N}$ 13'28', longitude $3^{\circ} \mathrm{E} 26^{\prime} 3^{\prime \prime}$ and altitude $133.8 \mathrm{~m}$ for DLRF. The average temperature, relative humidity and temperature-humidity index (THI) of the stations during the study were 26 and $28^{\circ} \mathrm{C}$, 86 and $85 \%$ (NiMET, 2019), and 27.1 and 28.3 (Bamidele et al., 2019) for SGS and DLR stations, respectively. Measurements of physiological and carcass characteristics were carried out in Ile-Ife, Osun State.

\section{Experimental birds and management}

The entire duration of the on-station test was 72 weeks, and commenced in May 2016. However, at 20 weeks, a total of 120 male birds (ten birds per breed per station, making 20 birds per breed) were randomly selected for morphometric analysis and carcass evaluation. The management of all the birds $(1,939)$ during the brooder and grower phases were as described by Bamidele et al. (2019). The locallydeveloped breeds (FUNAAB Alpha, Noiler and ShikaBrown), imported breeds (Kuroiler and Sasso), and local breed (Fulani) were brooded for 42 days. After which the birds were sexed and raised separately for additional 98 days. Commercial feeds (Chick mash: 2,993 kcal ME kg-1 $22.3 \%$ CP; Grower mash: 3,013 kcal ME kg-1 $17 \% \mathrm{CP}$ ) and water were made available ad libitum. The study was conducted as a randomized complete block design. All applicable international, national, and institutional guidelines for the care and use of animals were followed. The International Livestock Research Institute Institutional Animal Care and Use Committee (ILRI IACUC) approved the study, with reference number: IACUCRC2016.26. The veterinary permits obtained for the importation and use of the two foreign breeds (Kuroiler and Sasso) for research purposes have been described by Bamidele et al. (2019).

\section{Data collection and analysis}

Feed intake and mortality were recorded daily while body weights were taken every fourteen days. Rectal temperatures were taken at 138-140 days only on birds to be slaughtered. Birds were rested for a day and fasted overnight before slaughtering. Blood samples were collected during slaughtering into $5 \mathrm{ml}$ EDTA and $5 \mathrm{ml}$ plain bottles for determination of packed cell volume (PCV), red blood cells (RBC), white blood cells (WBC) and hemoglobin ( $\mathrm{Hb})$ content as described by Durosinmi (2005). Un-eviscerated carcasses were stored at $-4^{0}$ $\mathrm{C}$ for 12 hours in a chest freezer (LG, 


\section{Oyewale, Bamidele, Oyedele and Sonaiya}

GCS325GV, China) to facilitate measurement of the abdominal fat according to the methods of Sonaiya and Benyi (1983). Carcasses were cut up and weights taken of carcass, heart, liver, abdominal fat, leg muscle (thigh and drumstick), wing and breast muscle. Percent carcass composition of muscle, skin and bone were calculated. Proximate analysis was carried out on feed samples and muscle samples according to AOAC (2000). Data were analysed using analysis of variance procedure of the R Statistical Package R-3.2.2 (2017). The differences between breed means and stations means were separated using Duncan Multiple Range test.

The statistical model used was:

$\mathrm{Y}_{\mathrm{ijk}}=\beta_{0}+\mathrm{B}_{\mathrm{i}}+\mathrm{S}_{\mathrm{j}}+(\mathrm{B} * \mathrm{~S})_{\mathrm{ij}}+\varepsilon_{\mathrm{ijk}}$

Where

$\mathrm{Y}_{\mathrm{ijk}} \quad=$ Observation of the $\mathrm{k}^{\text {th }}$ population, of the $i^{\text {th }}$ breed and $j^{\text {th }}$ station

$\beta 0=$ Population mean

$\mathrm{Bi} \quad=$ Fixed effect of $i^{\text {th }} \operatorname{breed}(\mathrm{i}=6)$

$\mathrm{Sj} \quad=$ Fixed effect of $\mathrm{j}^{\text {th }}$ station $(\mathrm{j}=2)$

$(\mathrm{B} * \mathrm{~S}) \mathrm{ij}=$ Fixed $\left(\right.$ breed $^{*}$ station $)$ interaction effects

eijk $=$ Random error

\section{Results}

Bamidele et al. (2019) have previously reported the results of the live performance, mortality and feed intake during the entire testing period.

\section{Morphometric characteristics}

Kuroiler, Sasso and Noiler had higher Body Length (BL) than ShikaBrown and FUNAAB Alpha, which had longer BL than Fulani $(p<0.01)$. The dry feather weight of Fulani (66.1g) was lower $(p<0.01)$ than those of the other breeds.
Birds raised in the DLRF Zone had higher body length (BL) and shank length but lower feather weight $(p<0.01)$ than those raised in the SGS Zone. (Table 1)

Haematology and physiological characteristics

The PCV for Noiler (28.5\%) differed $(\boldsymbol{p}<0.01)$ from FUNAAB Alpha $(33.7 \%)$ which did not differ from the four other breeds (Table 2). RBC was not different across the breeds. Noiler had the lowest WBC. Fulani and FUNAAB Alpha had the highest $(\boldsymbol{p}<0.01) \mathrm{Hb}$. Rectal temperature (RT) of Kuroiler, Noiler and Sasso were higher than those of Fulani, FUNAAB Alpha and ShikaBrown. Hb and RT of birds raised in DLRF were higher than those of birds raised in SGS.

\section{Carcass characteristics}

Noiler had the highest $(\boldsymbol{p}<0.01)$ dressing percent - DP (69.3\%) while Fulani had the lowest $(60.9 \%)$. The DP of FUNAAB Alpha, Kuroiler, Sasso and ShikaBrown were not different. The heart weight, liver weight and lung weight as proportions of the live weight were highest $(\boldsymbol{p}<0.05)$ for the Fulani. Kuroiler and Sasso had the highest total muscle weight (TMW). FUNAAB Alpha and Noiler had lower TMW than Kuroiler and Sasso. Muscles made up 56.3 to $79.7 \%$ of the carcass weight for the breeds under study. The calculated muscle to bone ratio of all the breeds except Fulani exceeded 2.0. Noiler had the lowest $(\boldsymbol{p}<0.01)$ abdominal fat weight (AFW) while FUNAAB Alpha had the highest AFW. The live weight, carcass weight, total skin weight and TMW of birds raised in DLRF were higher $(\boldsymbol{p}<0.01)$ than those raised in SGS (Table 3). 


\section{Morphometrics and carcass characteristics of males of six dual purpose chicken breeds}

Table 1: Morphometric characteristics of the six tested breeds

\begin{tabular}{lcccccc|ccc}
\hline \multicolumn{1}{c}{ Characteristics } & \multicolumn{3}{c}{ Breed } & \multicolumn{2}{c}{ Station } \\
& Fulani & $\begin{array}{c}\text { FUNAAB } \\
\text { Alpha }\end{array}$ & Kuroiler & Noiler & Sasso & $\begin{array}{c}\text { Shika } \\
\text { Brown }\end{array}$ & SGS & DLRF \\
\hline Body Height $(\mathrm{cm})$ & $23.4^{\mathrm{c}}$ & $28.6^{\mathrm{b}}$ & $31.5^{\mathrm{a}}$ & $28.7^{\mathrm{b}}$ & $30.3^{\mathrm{a}}$ & $28.1^{\mathrm{b}}$ & 28.2 & 28.6 \\
Body Length $(\mathrm{cm})$ & $31.7^{\mathrm{c}}$ & $39.6^{\mathrm{b}}$ & $45.8^{\mathrm{a}}$ & $44.5^{\mathrm{a}}$ & $45.1^{\mathrm{a}}$ & $40.3^{\mathrm{b}}$ & $39.9^{\mathrm{b}}$ & $41.2^{\mathrm{a}}$ \\
Shank Length $(\mathrm{cm})$ & $8.8^{\mathrm{e}}$ & $9.4^{\mathrm{d}}$ & $13.2^{\mathrm{a}}$ & $10.0^{\mathrm{c}}$ & $12.5^{\mathrm{b}}$ & $10.2^{\mathrm{c}}$ & $10.3^{\mathrm{b}}$ & $11.2^{\mathrm{a}}$ \\
Wing Length $(\mathrm{cm})$ & $32.4^{\mathrm{b}}$ & $35.5^{\mathrm{a}}$ & $35.9^{\mathrm{a}}$ & $24.8^{\mathrm{b}}$ & $36.2^{\mathrm{a}}$ & $37.0^{\mathrm{a}}$ & $33.2^{\mathrm{a}}$ & 34.1 \\
Dry Feather Weight $(\mathrm{g})$ & $66.1^{\mathrm{b}}$ & $120.9^{\mathrm{a}}$ & $121.4^{\mathrm{a}}$ & $126.2^{\mathrm{a}}$ & $116.5^{\mathrm{a}}$ & $125.1^{\mathrm{a}}$ & $115.2^{\mathrm{a}}$ & $111.0^{\mathrm{b}}$ \\
\hline
\end{tabular}

Table 2: Haematology and physiological characteristics of the six tested breeds

\begin{tabular}{|c|c|c|c|c|c|c|c|c|}
\hline Characteristics & $\begin{array}{l}\text { Breed } \\
\text { Fulani }\end{array}$ & $\begin{array}{l}\text { FUNAAB } \\
\text { Alpha }\end{array}$ & Kuroiler & Noiler & Sasso & $\begin{array}{l}\text { Shika } \\
\text { Brown }\end{array}$ & $\begin{array}{l}\text { Station } \\
\text { SGS }\end{array}$ & DLRF \\
\hline $\mathrm{PCV}, \%$ & $32.2^{\mathrm{ab}}$ & $33.7^{\mathrm{a}}$ & $31.8^{\mathrm{ab}}$ & $28.5^{\mathrm{c}}$ & $30.3^{b c}$ & $31.8^{\mathrm{ab}}$ & 32.0 & 31.9 \\
\hline RBC, $x 10^{11}$ cells L ${ }^{-1}$ & 25 & 27 & 30 & 27 & 28 & 26 & 27 & 28 \\
\hline WBC, $x 10^{10}$ cells L $\mathrm{L}^{-1}$ & $10^{\mathrm{a}}$ & $8^{a}$ & $8.4^{\mathrm{a}}$ & $1.4^{\mathrm{b}}$ & $7^{\mathrm{a}}$ & $9^{a}$ & 8 & 9 \\
\hline Hemoglobin, $\mathrm{g} \mathrm{dL}^{-1}$ & $8.8^{\mathrm{a}}$ & $9.3^{\mathrm{a}}$ & $6.7^{\mathrm{cd}}$ & $7.2^{\mathrm{bc}}$ & $6.4^{\mathrm{d}}$ & $7.6^{\mathrm{b}}$ & $7.3^{\mathrm{b}}$ & $8.0^{\mathrm{a}}$ \\
\hline Rectal temperature, ${ }^{\circ} \mathrm{C}$ & $38.5^{\mathrm{c}}$ & $38.4^{\mathrm{c}}$ & $42.1^{\mathrm{ab}}$ & $41.6^{\mathrm{b}}$ & $42.4^{\mathrm{a}}$ & $38.2^{\mathrm{c}}$ & $38.9^{\mathrm{b}}$ & $41.4^{\mathrm{a}}$ \\
\hline
\end{tabular}

${ }^{a-d}$ Means with different superscripts on the same row were different at $p \leq 0.05, \mathrm{SGS}=$ Southern Guinea

Savanna, DLRF = Dry Lowland Rain Forest

Table 3: Carcass characteristics of the six tested breeds

\begin{tabular}{lcccccc|cc}
\hline & \multicolumn{5}{c|}{ Breed } & \multicolumn{2}{c}{ Station } \\
Characteristics & Fulani & $\begin{array}{c}\text { FUNAAB } \\
\text { Alpha }\end{array}$ & Kuroiler & Noiler & Sasso & $\begin{array}{c}\text { Shika } \\
\text { Brown }\end{array}$ & SGS & DLRF \\
\hline Live weight (LW), g & $1,328^{\mathrm{e}}$ & $2,565^{\mathrm{b}}$ & $2,875^{\mathrm{a}}$ & $2,249^{\mathrm{c}}$ & $2,886^{\mathrm{a}}$ & $1,876^{\mathrm{d}}$ & $2,228^{\mathrm{b}}$ & $2,380^{\mathrm{a}}$ \\
Carcass weight, g & $808^{\mathrm{d}}$ & $1,699^{\mathrm{ab}}$ & $1,821^{\mathrm{a}}$ & $1,572^{\mathrm{b}}$ & $1,851^{\mathrm{a}}$ & $1,154^{\mathrm{c}}$ & $1,442^{\mathrm{b}}$ & $1,534^{\mathrm{a}}$ \\
Dressing percentage, \% & $60.9^{\mathrm{c}}$ & $65.8^{\mathrm{ab}}$ & $63.2^{\mathrm{bc}}$ & $69.3^{\mathrm{a}}$ & $64.0^{\mathrm{bc}}$ & $61.6^{\mathrm{bc}}$ & 64.6 & 63.7 \\
Heart weight, \% of LW & $0.7^{\mathrm{a}}$ & $0.6^{\mathrm{ab}}$ & $0.4^{\mathrm{d}}$ & $0.5^{\mathrm{cd}}$ & $0.4^{\mathrm{d}}$ & $0.6^{\mathrm{bc}}$ & 0.5 & 0.5 \\
Liver weight, \% of LW & $1.9^{\mathrm{a}}$ & $1.5^{\mathrm{b}}$ & $1.6^{\mathrm{b}}$ & $1.9^{\mathrm{a}}$ & $1.7^{\mathrm{ab}}$ & $1.6^{\mathrm{ab}}$ & 1.7 & 1.7 \\
Lung weight, \% of LW & $0.9^{\mathrm{a}}$ & $0.7^{\mathrm{b}}$ & $0.7^{\mathrm{b}}$ & $0.8^{\mathrm{b}}$ & $0.7^{\mathrm{b}}$ & $0.7^{\mathrm{b}}$ & 0.7 & 0.7 \\
Total bone weight, g & $253^{\mathrm{e}}$ & $464^{\mathrm{b}}$ & $542^{\mathrm{a}}$ & $422^{\mathrm{c}}$ & $523^{\mathrm{a}}$ & $345^{\mathrm{d}}$ & 421 & 431 \\
Total muscle weight, g & $455^{\mathrm{d}}$ & $1,024^{\mathrm{b}}$ & $1,375^{\mathrm{a}}$ & $1,108^{\mathrm{b}}$ & $1,475^{\mathrm{a}}$ & $655^{\mathrm{c}}$ & $979^{\mathrm{b}}$ & $1,061^{\mathrm{a}}$ \\
Total skin weight, g & $9.7^{\mathrm{c}}$ & $202.7^{\mathrm{a}}$ & $213.3^{\mathrm{a}}$ & $197.8^{\mathrm{a}}$ & $206.7^{\mathrm{a}}$ & $153.4^{\mathrm{b}}$ & $174.9^{\mathrm{b}}$ & $184.2^{\mathrm{a}}$ \\
Abdominal fat, g & $9.4^{\mathrm{ab}}$ & $14.5^{\mathrm{a}}$ & $10.9^{\mathrm{ab}}$ & $1.3^{\mathrm{c}}$ & $8.5^{\mathrm{ab}}$ & $7.3^{\mathrm{bc}}$ & 10.08 & 7.20 \\
\hline a-e Means with different superscripts on the same row were different at $p \leq 0.05$, SGS $=$ Southern Guinea Savanna, \\
DLRF = Dry Lowland Rain Forest
\end{tabular}

Table 4: Proximate content of muscles from the six tested breeds

\begin{tabular}{lllllll|ll}
\hline \multirow{2}{*}{ Characteristics } & $\begin{array}{l}\text { Breed } \\
\text { Fulani }\end{array}$ & $\begin{array}{l}\text { FUNAAB } \\
\text { Alpha }\end{array}$ & Kuroiler & Noiler & Sasso & $\begin{array}{l}\text { Shika } \\
\text { Brown }\end{array}$ & $\begin{array}{l}\text { Station } \\
\text { SGS }\end{array}$ & DLRF \\
\hline Moisture (\%) & $66.6^{\mathrm{c}}$ & $67.3^{\mathrm{bc}}$ & $69.2^{\mathrm{b}}$ & $75.3^{\mathrm{a}}$ & $69.5^{\mathrm{b}}$ & $67.8^{\mathrm{bc}}$ & $68.8^{\mathrm{a}}$ & $69.8^{\mathrm{a}}$ \\
CP $(\%)$ & $25.0^{\mathrm{a}}$ & $25.4^{\mathrm{a}}$ & $23.3^{\mathrm{b}}$ & $21.3^{\mathrm{c}}$ & $23.6^{\mathrm{b}}$ & $24.1^{\mathrm{ab}}$ & $23.7^{\mathrm{a}}$ & $23.9^{\mathrm{a}}$ \\
Ash $(\%)$ & $1.6^{\mathrm{a}}$ & $1.3^{\mathrm{cd}}$ & $1.3^{\mathrm{bc}}$ & $1.0^{\mathrm{ab}}$ & $1.7^{\mathrm{a}}$ & $1.6^{\mathrm{ab}}$ & $1.4^{\mathrm{a}}$ & $1.4^{\mathrm{a}}$ \\
Fat (\%) & $2.5^{\mathrm{ab}}$ & $2.8^{\mathrm{ab}}$ & $2.6^{\mathrm{ab}}$ & $1.5^{\mathrm{c}}$ & $2.8^{\mathrm{a}}$ & $2.3^{\mathrm{b}}$ & $2.2^{\mathrm{b}}$ & $2.6^{\mathrm{a}}$ \\
Fiber (\%) & 0.02 & 0.02 & 0.02 & 0.02 & 0.02 & 0.02 & 0.02 & 0.02 \\
Energy (kcal kg $\left.)^{-1}\right)$ & $1,074^{\mathrm{b}}$ & $1,169^{\mathrm{a}}$ & $1,077^{\mathrm{b}}$ & $916^{\mathrm{c}}$ & $1,104^{\mathrm{ab}}$ & $1,078^{\mathrm{b}}$ & $1,056^{\mathrm{a}}$ & $1,082^{\mathrm{a}}$ \\
\hline
\end{tabular}

${ }^{\mathrm{a}-\mathrm{d}}$ Means with different superscripts on the same row were different at $p \leq 0.05$, SGS = Southern Guinea Savanna, DLRF $=$ Dry Lowland Rain Forest 


\section{Oyewale, Bamidele, Oyedele and Sonaiya}

\section{Proximate analysis}

Noiler muscle had the highest moisture content and the lowest fat content $(\boldsymbol{p}<0.01)$. The crude protein (CP) of the muscles of locally developed breeds (except Noiler) were not different from one another, but was higher (except Shikabrown ${ }^{\circledR}$ ) than the CP of the muscles of foreign developed breeds $(\boldsymbol{p}<0.01)$ (Table 4). Noiler muscle had the lowest CP. Sasso muscle had the highest fat content which was not different from the fat contents of Fulani, FUNAAB Alpha and Kuroiler. The fat content of ShikaBrown muscle was lower than that of Sasso but not different from those of Fulani, FUNAAB Alpha and Kuroiler $(\boldsymbol{p}<0.01)$. Noiler muscle had the lowest fat content $(1.5 \%)$. The muscle of FUNAAB Alpha had the highest fat content, which was different from those of the other breeds except Sasso. Except for fat in which birds raised at DLRF had higher content $(\boldsymbol{p}<0.01)$ than those raised at SGSZ, there was no difference between proximate contents of birds raised at the two locations.

\section{Discussion}

The body length (BL) of indigenous cocks in South-Western Ethiopia (41 cm) (Tadele et al., 2018) was higher than BL for Fulani, FUNAAB Alpha and Shikabrown ${ }^{\circledR}$ but lower than the values of Kuroiler, Noiler and Sasso. The shank length of the six breeds investigated were longer than the value reported by the same authors. The lower feather weight of birds raised in the DLRF may be due to the higher temperature of the zone. This agrees with Cooper and Washburn (1998) that birds raised under lower ambient temperature tend to grow more feathers. The PCV, RBC and $\mathrm{Hb}$ fall within the normal range for chickens (Ladokun et al., 2008; CCAC 2017). Three breeds (Fulani, FUNAAB Alpha and ShikaBrown) had lower RT but three breeds (Noiler, Kuroiler and Sasso) had higher RT than those reported by CCAC (2017) and
Isidahomen et al. (2012). The higher $\mathrm{Hb}$ content and RT recorded for birds raised at DLRF can be attributed to higher temperature and higher THI, respectively (Donkoh, 1989). The DP of the six breeds were below the values recorded by Hui et al. (2001) and (Lamptey et al., 2015) for broiler chicken. This was understandable since chickens in this study were dual purpose breeds. Except for Kuroiler and Sasso, the DP of the breeds were similar to those reported by Ndzi et al. (2016). Breeds that had higher BL were observed to have higher BW, and particularly, higher DP, which supports the report that BW and BL can be used as proxy indicators of production traits because of their strong correlations to these traits (FAO 2012). The lower HW observed for Kuroiler and Sasso, which had the highest LW, was probably due to the proportion of space occupied by the much larger muscles in these breeds when compared with the others (Hassanzadeh et al., 2005). The liver weight of all the six breeds were lower than the values reported by Ndzi et al. (2016) while their lung weights were higher than those reported by the same author. The proportion of muscle observed in this study (56.3 to $79.7 \%$ ) is higher than the $51 \%$ calculated from the data of Hui et al. (2001). The muscle to bone ratio is lower than the value of 3.6 reported by Shahin and Elazeem (2005) for broiler chickens. The higher energy content of FUNAAB Alpha and Sasso is connected to the higher fat contents of the breeds since fat provides more calories for energy (Thompson 2010). It can be concluded that the six breeds were able to adjust to the hot humid environment of the study locations. The hierarchy, in descending order, of physiological characteristics, morphometric measurements, and carcass characteristics is as follows: Kuroiler, FUNAAB Alpha, Noiler, Sasso, ShikaBrown and Fulani. Furthermore, the data from this study will be useful to breeders for seed stock 
Morphometrics and carcass characteristics of males of six dual purpose chicken breeds

development.

\section{Acknowledgement}

The collaboration of the International Livestock Research Institute in sourcing Kuroiler and Sasso hatchable eggs and funding from the Bill and Melinda Gates Foundation (Grant No.: OPP1112198) are acknowledged. The authors acknowledge the contributions of Babatunde, A. (in the laboratory determination of the physiological parameters) and Adetunji, P.O., Oyewale, A.O., Ajibola, O.I. and Osoniyi, O.O. for their contribution to sample collection.

\section{References}

Association of Official Analytical Chemists 2000. Official methods of analysis of the AOAC (18 ed.). Washington, DC, USA.

Bamidele, O., Sonaiya, E. B., Adebambo, O. A. and Dessie, T. 2019. Onstation performance evaluation of improved tropically adapted chicken breeds for smallholder poultry production systems in Nigeria. Tropical Animal Health and Production 52: 1541-1548 https://doi.org/10.1007/s11250019-02158-9

Canadian Council on Animal Care 2017. Guide to the Care and Use of Experimental Animals CCAC Volume 1, 2ed. 166 - 168.

Cooper, M. A. and Washburn, K. W. 1998. The Relationships of Body Temperature to Weight Gain, Feed Consumption, and Feed Utilization in Broilers under Heat Stress. Poultry Science 77: 237-242. [Accessed May 21. 2020] https://pdfs.semanticscholar.org/17 79/491f8c2fc1e6fb46b74069a476f e39aba46a.pdf

Donkoh, A. 1989. Ambient temperature: a factor affecting performance and physiological response of broiler chickens. International Journal of Biometeorology 33 (4): 259-265.

Durosinmi, M. A. 2005. Haematology and Immunology Practical Guide for Dental and Medical Students. Department of Haematology and Immunology, Obafemi Awolowo University, Ile-Ife, Nigeria.

Food and Agriculture Organization 2012. Phenotypic characterization of animal genetic resources. FAO Animal Production and Health Guidelines No.11. Rome. [Accessed $\mathrm{M}$ a y $\quad 21, \quad 2 \quad 0 \quad 2 \quad 0]$ http://www.fao.org/docrep/015/i26 86e/i2686e00.pdf

Hassanzadeh, M., Gilanpour, H., Charkhkar, S., Buyse, J., and Decuypere, E. 2005. Anatomical parameters of cardiopulmonary system in three different lines of chickens: further evidence for involvement in ascites syndrome, Avian Pathology, 34 (3): 188-193. [Accessed May 21, 2020] http://www.tandfonline.com/doi/pd f/10.1080/03079450500096372

Hui, Y. H., Nip, W., Rogers, R. W. and Young, O. A. 2001. Meat Science and Applications. Marcel Dekker, New York, NY, USA.

Isidahomen, C. E., Njidda, A. A. and Olatunji, E. A. 2012 .Heat Tolerant Traits among Local and Exotic Chickens in Southern Nigerian. IOSR Journal of Agriculture and Veterinary Science, 1 (6): 31-36

Ladokun, A. O., Yakubu, A., Otite, J. R., Omeje, J. N., Sokunbi, O. A. and Onyeji, E. 2008. Haematological and serum biochemical indices of naked neck and normally feathered indigenous chickens in a sub humid tropical environment. International Journal of Poultry Science 7 (1): 5558. 
Oyewale, Bamidele, Oyedele and Sonaiya

Lamptey, V. K., Hagan, B. A., AsafuAdjaye, A., Adu-Aboagye, G., Darfour-Oduro, K. A. and BoaAmponsem, K. 2015. Phenotypic Profiles of Exotic Broiler Genotypes in Ghana Journal of Animal Science Advances, 5(9): 1392-1397

Ndzi, N. H., Christian, K. T., Pascal, M. T. F. and Ndamukong, K. J. N. 2016. Effect of Euphorbia hirta and Thymus vulgaris powders on performance and haematological parameters of the Cameroon Kabir Chicken. Bull. Anim. Health. Prod. Afr. 64: 55-68.

NiMET 2019 Nigerian Metrological Agency daily weather for 2016 2018. https://nimet.gov.ng/dailyweather

R Core Team 2017. R: A language and environment for statistical computing. R Foundation for Statistical Computing, Vienna, Austria URL https://www.Rproject.org/.

Shahin, K. A. and Elazeem, F. A. 2005. Effects of breed, sex and diet and their interactions on carcass composition and tissue weight distribution of broiler chickens. Archiv fur Tierzucht 48 (6): 612626.
Sonaiya, E. B. and Benyi, K. 1983. Abdominal fat in twelve to sixteenweek-old broiler birds as influenced by age, sex and strain. Poultry Science 62: 1793 -1799.

Sonaiya, E. B. and Swan, S. E. J. 2004. Small-Scale Poultry Production. FAO Animal Production and Health Manual. Rome

Sonaiya, E. B., Branckaert, R. D. S. and Gueye, E. F. 1999. Research and development options for family poultry. First INFPD/FAO Electronic Conference on Family Poultry.

Tadele, A., Melesse, A. and Taye, M. 2018. Phenotypic and morphological characterizations of indigenous chicken populations in Kaffa Zone, South-Western Ethiopia. Animal Husbandry Dairy and Veterinary Science 2: D O I : 10.15761/AHDVS.1000128

Thompson, L. D. 2010 Nutritive value of poultry meat P 355-368 In: Owens, C. M., Alvarado, C. Z. and Sams, A. R. eds Poultry Meat Processing. 2ed CRC Press, Taylor and Francis Group.

Received: $12^{\text {th }}$ October, 2020 Accepted: $5^{\text {th }}$ February, 2021 